\title{
PENGARUH STRATEGI PEMBELAJARAN DAN MOTIVASI BERPRESTASI TERHADAP HASIL BELAJAR BAHASA INDONESIA
}

\author{
Farida Nurmalasari ${ }^{1}$, Sahat Siagian ${ }^{2}$, R. Mursid $^{3}$ \\ ${ }^{1}$ Sekolah Dasar Negeri 106162 Medan Estate, ${ }^{2,3}$ Pascasarjana Universitas Negeri Medan \\ farida_nurmalasari@gmail.com
}

\begin{abstract}
Abstrak: Tujuan penelitian ini adalah: (1) mengetahui perbedaan hasil Pembelajaran kelompok siswa yang dibelajarkan dengan strategi pembelajaran berbasis Accelerated Learning dan strategi pembelajaran Direct Intructional pada mata pelajaran bahasa Indonesia, (2) mengetahui perbedaan hasil belajar bahasa Indonesia antara kelompok siswa yang memiliki motivasi berprestasi tinggi dan rendah, dan (3) interaksi antara strategi pembelajaran dan motivasi berprestasi siswa terhadap hasil belajar bahasa Indonesia. Populasi dalam penelitian ini adalah siswa kelas V SD Negeri No 106162 Medan Estate dan SDIT Al-Hijrah 2 Lau Dendang. Teknik penarikan sampel dilakukan dengan cluster random sampling. Teknis analisis ini adalah ANAVA dua jalur pada taraf signifikansi $\alpha=0,05$ yang dilanjutkan dengan uji Scheffe. Hasil penelitian menunjukkan: (1) rata-rata hasil belajar siswa yang dibelajarkan dengan strategi pembelajaran berbasis Accelerated Learning lebih tinggi daripada dengan strategi pembelajaran Direct, (2) rata-rata hasil belajar siswa dengan motivasi berprestasi tinggi lebih tinggi dengan motivasi berprestasi rendah, dan (3) terdapat interaksi antara strategi pembelajaran dengan motivasi berprestasi terhadap hasil belajar bahasa Indonesia. Dari hasil analisis data disimpulkan bahwa siswa dengan karakteristik motivasi berprestasi tinggi maka strategi pembelajaran yang tepat digunakan adalah strategi pembelajaran berbasis Accelerated Learning dan siswa dengan karakteristik motivasi berprestasi rendah, maka strategi pembelajaran yang tepat digunakan adalah strategi pembelajaran Direct Instructional.
\end{abstract}

Kata Kunci: strategi pembelajaran, accelerated learning, direct instructional, motivasi berprestasi, bahasa

\begin{abstract}
The purpose of this study are: (1) to find out the difference in learning outcomes of groups of students who are taught with learning strategies based on Accelerated Learning and Direct Intructional learning strategies in Indonesian subjects, (2) find out the differences in Indonesian learning outcomes between groups of students who have motivation high and low achievers, and (3) the interaction between learning strategies and students' achievement motivation towards Indonesian learning outcomes. The population in this study were grade V students of SD Negeri No 106162 Medan Estate and SDIT Al-Hijrah 2 Lau Dendang. The sampling technique is done by cluster random sampling. The technical analysis is twoway ANOVA at the significance level $\alpha=0.05$ followed by the Scheffe test. The results showed: (1) the average learning outcomes of students who were taught with learning strategies based on Accelerated Learning were higher than those with Direct learning strategies, (2) the average learning outcomes of students with higher achievement motivation with higher achievement motivation, and (3) there is an interaction between learning strategies and achievement motivation on Indonesian learning outcomes. From the results of data analysis, it was concluded that students with high achievement motivation characteristics then the appropriate learning strategy used was Accelerated Learning based learning strategy and students with low achievement motivation characteristics, then the right learning strategy used was Direct Instructional learning strategy.
\end{abstract}

Keywords: learning strategies, accelerated learning, direct instructional, achievement motivation, language

\section{PENDAHULUAN}

Keterampilan berbahasa bermanfaat dalam melakukan interaksi dalam masyarakat dan dalam suatu peristiwa komunikasi seringkali beberapa jenis keterampilan bahasa digunakan secara bersama-sama guna mencapai tujuan komunikasi. Sejalan dengan perkembangan zaman, fungsi bahasa sebagai alat komunikasi semakin tinggi, karena komunikasi tidak akan terjadi tanpa bahasa. Menurut Sumantri (2005) bahasa adalah serangkaian bunyi yang digunakan sebagai alat komunikasi berupa kata-kata yang memiliki arti tertentu. Bahasa Indonesia merupakan bahasa nasional yang digunakan sebagai bahasa pengantar disekolah juga dalam pergaulan. Keraf (2004) mendefinisikan bahwa bahasa adalah alat komunikasi antar anggota masyarakat yang berupa sistem lambang bunyi yang bermakna yang dihasilkan oleh alat ucap manusia. 
Permendiknas Nomor 22 Tahun 2006 tentang standar isi untuk satuan pendidikan dasar dan menengah, standar isi bahasa Indonesia merupakan kualifikasi kemampuan minimal peserta didik yang menggambarkan penguasaan pengetahuan, keterampilan berbahasa dan sikap positif terhadap bahasa dan sastra Indonesia. Standar kompetensi ini merupakan dasar bagi peserta didik memiliki kemampuan : (1) berkomunikasi secara efektif dan efisien sesuai dengan etika yang berlaku, baik secara lisan maupun tulis; (2) menghargai dan bangga menggunakan bahasa Indonesia sebagai bahasa persatuan dan bahasa Negara; (3) memahami bahasa Indonesia dan menggunakannya dengan tepat dan kreatif untuk berbagai tujuan; (4) menggunakan bahasa Indonesia untuk meningkatkan kemampuan intelektual serta kematangan emosional dan sosial; (5) menikmati dan memanfaatkan karya sastra untuk memperluas wawasan, memperhalus budi pekerti serta meningkatkan pengetahuan dan kemampuan berbahasa; (6) menghargai dan membanggakan sastra Indonesia sebagai khazanah budaya dan intelektual manusia Indonesia. Ruang lingkup mata pelajaran bahasa Indonesia mencakup komponen kemampuan berbahasa dan kemampuan bersastra yang meliputi aspekaspek mendengarkan, berbicara, membaca dan menulis.

Hamalik memandang pembelajaran sebagai suatu sistem, sedangkan Reigeluth (1983) mengemukakan tiga komponen utama dalam pembelajaran yaitu metode, kondisi dan hasil. Hubungan metode, kondisi dan hasil dalam pembelajaran dari sisi variabel satu sama lain berpengaruh. Variabel kondisi dan metode merupakan variabel bebas dan kedua variabel ini berinteraksi sehingga menghasilkan efek pada hasil belajar sebagai variabel terikat. Oleh karena itu strategi pembelajaran memiliki kaitan yang sangat erat terhadap hasil belajar, karena kesesuaian dan keefektifan strategi pembelajaran mempengaruhi kualitas dan kuantitas hasil belajar.

Jika hal ini karena faktor pendekatan atau metode, maka guru harus segera memperbaiki bentuk pengajaran yang diberikan. Memang tidak ada satu pun bentuk pendekatan atau metode yang cocok untuk satu materi pembelajaran. Setiap metode memiliki kelebihan dan kekurangan masing-masing. Guru dapat mengkombinasikan metode yang akan digunakan sesuai dengan kebutuhan proses belajar mengajar. Penggunaan metode yang tepat akan menghasilkan pembelajaran yang efektif, efisien dan memiliki daya tarik bagi siswa. (Miarso, 2004).

Disamping pemilihan strategi pembelajaran yang tepat, untuk memperoleh hasil belajar suatu kegiatan pembelajaran juga dipengaruhi oleh kemampuan guru dalam mengenal dan memahami karakteristik siswa. Dick \& Carey (2006) mengatakan bahwa seorang guru hendaknya mampu mengenal dan mengetahui karakteristik siswa, sebab pemahaman yang baik terhadap karakteristik siswa akan sangat berpengaruh terhadap keberhasilan proses belajar siswa. Karena jika seorang guru dapat mengetahui karakteristik siswanya, maka selanjutnya guru dapat menyesuaikannya dengan metode pembelajaran yang hendak digunakan.

Selanjutnya Meclelland yang dikutip oleh Ratumanan (2002) menyatakan bahwa seseorang mempunyai motivasi untuk belajar atau bekerja karena adanya kebutuhan berprestasi. Motivasi disini merupakan fungsi dari tiga Variabel, yaitu harapan untuk melakukan tugas dengan berhasil, persepsi tentang nilai tugas, dan kebutuhan untuk keberhasilan atau sukses. Apabila seorang siswa memiliki motivasi berprestasi berarti dalam dirinya telah ada motivasi untuk belajar. Motivasi untuk berprestasi merupakan salah satu faktor pendukung dalam keberhasilan belajar. Seorang siswa yang memiliki motivasi prestasi akan lebih menguasai Keterampilan berbahasa, yakni mendengarkan atau menyimak, membaca, menulis maupun berbicara. Strategi pembelajaran yang berbeda akan berpengaruh terhadap proses dan hasil belajar, sedangkan motivasi berprestasi dalam diri siswa akan menggerakkan perilaku belajar.

\section{Hakikat belajar dan hasil belajar bahasa Indonesia}

Secara sederhana Gagne (1985) mendefinisikan belajar sebagai hasil dari interaksi antara individu dengan lingkungannya. Gagne (dalam Yamin, 2008:122) mendefinisikan belajar sebagai suatu proses dimana suatu organisme berubah perilakunya sebagai akibat pengalaman. Dengan kata lain bahwa belajar merupakan perubahan yang terjadi karena adanya usaha dan penguatan terhadap suatu pengetahuan dan informasi yang dilakukan secara teratur. Gagne memandang 
belajar sebagai proses perubahan perilaku akibat pengalaman yang dialaminya.

Belajar juga berarti perubahan tingkah laku, sikap, akhlak dalam proses pengalaman" (Rasyad, 2003:26). Dalam proses pengalaman ini, Hamalik dalam bukunya Proses Belajar Mengajar menyatakan bahwa: "Belajar adalah modifikasi atau memperteguh kelakuan melalui pengalaman "(learning is defined as the modification of streatening of behavior through experience), Hamalik (2005:27). Menurut Sadiman (2003), seseorang telah belajar ditandai dengan perubahan tingkah laku dalam dirinya, perubahan tingkah laku tersebut bukan saja menyangkut perubahan yang bersifat pengetahuan (kognitif) dan keterampilan (psikomotor) tetapi juga menyangkut nilai dan sikap (afektif).

Selanjutnya hasil belajar adalah tindakan konkrit yang terdiri atas demonstrasi pengetahuan, keterampilan atau nilai. Reigeluth (1983) mendefinisikan hasil belajar sebagai akibat yang dapat dipakai untuk mengukur kegunaan berbagai macam metode pembelajaran sebagai dalam berbagai kondisi. Menurutnya, hasil pembelajaran harus memiliki efektifitas, efesiensi dan daya tarik. Merril (1991) memastikan hasil pembelajaran harus selalu dikaitkan dengan pencapaian tujuan pembelajaran. Terhadap tujuh indikator yang dapat digunakan untuk menetapkan untuk menetapkan keefektifan suatu pembelajaran, yaitu: (1) kecerdasan penguasaan perilaku; (2) kecepatan unjuk kerja; (3) kesesuaian dengan prosedur; (4) kualitas hasil akhir; (5) tingkat hasil akhir; (6) tingkat retensi. Sementara itu efesiensi pengajaran diukur dengan rasio antara keefektifan dan jumlah waktu yang dipakai siswa dan jumlah biaya pengajaran yang digunakan. Indikator utama dalam mengukur efisiensi diacukan pada waktu, personalia dan sumber belajar yang terpakai. Dengan kata lain, jumlah waktu yang dibutuhkan oleh siswa untuk mencapai tujuan yang telah ditetapkan, jumlah personalia yang terlibat dalam pelaksanaan pengajaran dan penggunaan sumber belajar yang dirancang untuk pengajaran harus terhitung dengan cermat. Selanjutnya, berkaitan dengan daya tarik pengajaran dapat diukur dengan mengamati kecenderungan siswa untuk tetap terus belajar. Daya tarik pengajaran erat sekali kaitannya dengan daya tarik bidang studi dan kualitas pengajar. Menurut Sukmadinata (2008:124) hasil belajar merupakan suatu perilaku hasil belajar. Hasil belajar tersebut meliputi semua akibat dari proses belajar yang berlangsung di sekolah, belajar yang bersifat kognitif, efektif, maupun psikomotorik, sengaja ataupun tidak disengaja. Tidak termasuk ke dalam hasil belajar adalah perilaku-perilaku yang muncul sebagai akibat kematangan, penyakit ataupun sebab-sebab kimiawi.

Sudjana (2002) membagi tiga macam hasil belajar, yakni : (a) keterampilan dan kebiasaaan, (b) pengetahuan dan pengertian, (c) sikap dan cita-cita. Menurut Gagne (Abin,2003), perubahan perilaku yang merupakan hasil belajar dapat berbentuk : (1) Informasi verbal; yaitu penguasaan informasi dalam bentuk verbal, baik secara tertulis maupun tulisan, misalnya pemberian namanama terhadap suatu benda, definisi, dan sebagainya, (2) Kecakapan intelektual; yaitu keterampilan individu dalam melakukan interaksi dengan lingkungannya dengan menggunakan simbol-simbol, misalnya: penggunaan simbol matematika. Termasuk dalam keterampilan intelektual adalah kecakapan dalam membedakan (discrimination), memahami konsep konkrit, konsep abstrak, aturan dan hukum. Keterampilan ini sangat dibutuhkan dalam menghadapi pemecahan masalah, (3) Strategi kognitif; kecakapan individu untuk melakukan pengendalian dan pengelolaan keseluruhan aktivitasnya. Dalam konteks proses pembelajaran, strategi kognitif yaitu kemampuan mengendalikan ingatan dan caracara berfikir agar terjadi aktivitas yang efektif. Kecakapan intelektual menitikberatkan pada hasil pembelajaran, sedangkan strategi kognitif lebih menekankan pada pada proses pemikiran, (4) Sikap; yaitu hasil pembelajaran yang berupa kecakapan individu untuk memilih macam tindakan yang akan dilakukan. Dengan kata lain. Sikap adalah keadaan dalam diri individu yang akan memberikan kecenderungan vertindak dalam menghadapi suatu obyek atau peristiwa, didalamnya terdapat unsur pemikiran, perasaan yang menyertai pemikiran dan kesiapan untuk bertindak, (5) Kecakapan motorik; ialah hasil belajar yang berupa kecakapan pergerakan yang dikontrol oleh otot dan fisik.

Menurut Bloom dalam Sudjana (2009:22) mengklasifikasikan hasil belajar dalam tiga ranah yaitu ranah kognitif, afektif dan psikomotor. Ranah Kognitif terbagi dalam enam tingkatan yaitu ingatan, pemahaman, 
aplikasi, analisis, evaluasi dan kreatifitas. Ranah afektif terbagi menjadi lima tingkatan yaitu penerimaan, penganggapan, penghargaan, pengorganisasian dan penjatidirian. Ranah psikomotor terbagi menjadi empat tingkatan yaitu peniruan, manipulasi, artikulasi dan pengalamiahan.

Bahasa adalah satu sistem lambang bunyi yang bersifat arbiter, yang digunakan oleh sekelompok anggota masyarakat untuk berinteraksi dan mengidentifikasikan diri (Chaer, 2003:30). Brown (2000:93) menyatakan bahwa pembelajaran bahasa dapat menerapkan delapan tipe pembelajaran yang dicetuskan oleh Gagne, yaitu: (a) signal learning (belajar signal) manusia memeberikan respon tersendiri terhadap proses bahasa yang dipelajarinya; (b) stimulus-response learning ( belajar stimulus respon ) melalui proses belajar trial-error siswa akan memeperoleh pengalaman berbahasa, misalnya pengucapan bunyi seperti halnya yang dikatakan penutur aslinya; (c) chaining (rantai/rangkaian pemerolehan pola-pola bahasa yang terstruktur secara skuens/hierarki; (d) verbal association (asosiasi verbal) pemerolehan bahasa verbal dan non verbal; (e) discrimination learning (belajar diskriminasi) kesesuaian dalam pemerolehan dan perbedaan makna kata; (f) concept learning (belajar konsep) belajar konsep-konsep atau aturan bahasa, seperti sintaksis, morfologi; (g) principle learning (belajar prinsip) perluasan dari pembelajaran konsep atau pembentukan sistem linguistik yang lebih kompleks; (h) problem solving (pemecahan masalah) mengatasi masalah terkait pemerolehan bahasa, baik dari segi linguistik maupun interaksi.

Dalam lingkup bahasa, kompetensi merupakan pemerolehan sistem bahasa yang terkait dengan aturan tata bahasa, kosa kata dan komponen bahasa lainnya. Chomsky dalam Brown (2000) membedakan pemerolehan bahasa antara performa dan pemahaman. Performa merupakan produksi bahasa meliputi: berbicara dan menulis sedangkan pemahaman meliputi : keterampilan mendengar dan membaca.

Untuk mengetahui samapi dimana siswa berhasil dalam belajar dapat diketahui dengan memberikan penilaian atau evaluasi berupa tes hasil belajar. Fungsi dilakukannya evaluasi tersebut yaitu untuk mengetahui kemajuan dan perkembangan serta keberhasilan siswa setelah mengalami atau melakukan kegiatan belajar selama jangka waktu tertentu.
Selanjutnya Sudjana dan Rivai (2003) mengatakan bahwa penilaian hasil belajar bertujuan melihat kemjuan belajar para siswa dalam hal pennguasaan materi pembelajaran yang telah dipelajarinya sesuai dengan tujuantujuan yang telah ditetapkan.

\section{Hakikat Strategi Pembelajaran}

Gagne dan Briggs (1989) mengartikan pembelajaran sebagai suatu perangkat peristiwa yang mempengaruhi siswa agar terjadi proses belajar. Dick an Carey (2001: 189) mengemukakan bahwa: " an instructional strategy describes the general components of a set instructional materials and the procedures that will be used with those materials to enable students' mastery of learning outcomes. You should note that an instructional strategy is more than a simple outline of content that will be presented to the learner".

Pendapat yang dikemukakan Dick and Carey menjelaskan bahwa strategi pembelajaran berupa komponen-komponen umum dari suatu kesatuan bahan pembelajaran dan prosedur yang dibutuhkan untuk memberikan hasil belajar pada siswa yang berkenaan dengan pendekatan pengajaran dalam mengelola proses belajar untuk menyampaikan materi secara sistematik sehingga kemampuan yang diharapkan dapat dikuasai secara efektif dan efisien. Dick and Carey (2001:190) mengungkapkan adanya lima komponen umum dari strategi pembelajaran, yaitu: (1) kegiatan pra-pembelajaran; (2) penyajian informasi; (3) partisipasi siswa; (4) tes; dan (5) tindak lanjut. Sedangkan Gagne dalam Dick and Carey (2001:189) merumuskan kegiatan pembelajaran dalam sembilan langkah berikut: (a) mendapatkan perhatian; (b) memberitahukan tujuan kepada siswa; (c) menjelaskan kompetensi yang menjadi pra syarat; (d) menyajikan bahan stimulus; (e) memberikan arahan pembelajaran; (f) memunculkan penampilan siswa; (g) memberikan umpan balik; (h) menilai penampilan; dan (i) menambah retensi dan transfer.

Sependapat dengan pernyataan Dick and Carey, maka Suparman (2001: 167) menyatakan bahwa strategi pembelajaran merupakan cara sistematis dalam mengkomunikasikan isi pelajaran kepada siswa untuk mencapai tujuan intruksional tertentu. Miarso (2007:530) menyatakan strategi pembelajaran merupakan pendekatan menyeluruh pembelajaran dalam suatu sistem 
pembelajaran yang berupa pedoman umum dan kerangka kegiatan untuk mencapai tujuan umum pembelajaran, yang dijabarkan dari pandangan falsafah dan teori belajar tertentu. Sedangkan David dalam Sanjaya (2008:126) merumuskan strategi pembelajaran sebagai suatu perencanaan yang memuat tentang rangkaian kegiatan yang dirancang untuk mencapai tujuan pendidikan tertentu.

Dalam menyusun strategi pembelajaran, hal yang penting diperhatikan adalah karakteristik siswa berupa latar belakang dan pengalaman pebelajar yang berpengaruh terhadap efektifitas proses pembelajaran. Dick and Carey (2001:198) menjelaskan bahwa dalam penyusunan strategi sangatlah penting mempertimbangkan karakteristik siswa. Setiap individu akan mencapai hasil belajar sesuai tingkat kemampuan masing-masing, dan guru yang mampu memilih dan mendesain strategi pembelajaran yang sesuai dengan karakteristik siswa akan memperoleh tujuan yang di harapkan.

Selama beberapa tahun terakhir, banyak strategi pembelajaran yang dipercepat yang mulai sering diperbincangkan dan mulai diterapkan di sekolah- sekolah di Indonesia. Sebelumnya strategi serupa juga sudah popular di luar negeri di antaranya adalah Quantum Learning, Quantum Teaching, Super Learning, dan Efficient dan Effective Teaching. Strategi pembelajaran ini berkembang di dasarkan pada pengetahuan tentang cara kerja otak, cara kerja memori, Neuro Linguistic Programming, motivasi, konsep diri, kepribadian, perasaan, emosi, metakognisi, gaya berpikir, multiple intelligence, teknik memori, teknik membaca, mencatat dan teknik belajar lainnya. (Gunawan, 2006:2) Diantaranya berbagai strategi pembelajaran, strategi pembelajaran berbasis Accelerated Learning merupakan salah satu strategi yang relatif baru berupaya menemukan cara pengajaran terbaik.

\section{Strategi Pembelajaran Berbasis Accelerated Learning}

Prashing (2007) berbasis Accelerated Learning dikembangkan pada pertengahan 1970 oleh Dr. George Lozanov, seorang psikiater dan pendidik Bulgaria, Dr. G. Lozanov telah membuktikan bahwa proses belajar dapat dipercepat dengan cara tidak memberi suggesti kepada siswa tentang keyakinan-keyakinan yang terbatas. Ngermanto (2001) berbasis Accelerated Learning dapat didefinisikan sebagai pemberdayaaan siswa untuk belajar lebih cepat, lebih efektif dan lebih menyenangkan. Berbasis Accelerated Learning disebut juga Cara Belajar Cepat (CBC) yang merupakan sebuah upaya yang meningkatkan kualitas pendidikan siswa agar dapat belajar lebih cepat, mengingat lebih banyak dan berpikir lebih kreatif (Rose dan Nicholl, 2002:8)

Meier (2003:26) juga mengungkapkan bahwa" berbasis Accelerated Learning adalah pendekatan belajar yang paling maju yang digunakan pada masa sekarang, dan mempunyai banyak manfaat. Strategi pembelajaran berbasis Accelerated Learning didasarkan pada penelitian mutakhir mengenai otak dan belajar yang dapat menggunakan berbagai metode dan media. Bersifat terbuka dan luwes dimana pebelajar diajak sepenuhnya. Strategi Pembelajaran berbasis Accelerated Learning cocok dengan semua gaya belajar dan memberi energi dalam proses belajar. Strategi Pembelajaran berbasis Accelerated Learning membuat belajar menyenangkan dan benarbenar mementingkan hasil, hasil dan hasil. DePorter (2004:14) menyatakan bahwa strategi Pembelajaran berbasis Accelerated Learning dapat memungkinkan siswa untuk belajar dengan kecepatan yang mengesankan dengan upaya yang normal dan dibarengi kegembiraan, dimana startegi pemebelajaran berbasis Accelerated Learning berusaha memadukan musik, permainan, warna, cara belajar positif dan suasana belajar yang menyenangkan sehingga kegiatan pembelajaran menjadi lebih bermakna dan menyenangkan dengan daya ingat yang kuat.

Menurut Donal Hebb dalam Darmawan (2009:128) ada dua tipe kemampuan intelegensi manusia, Pertama, intelegensi sebagai potensi individu yang harus dikembangkan. Kedua, intelegensi sebagai bentuk tingkat kemampuan dari penampilan atau spesifikasi yang dimiliki individu untuk mengembangkan kemampuannya.

Menurut Walberg dan Greenberg yang dikutip De Porter (2004:19, 374) lingkungan sosial adalah penentu psikologis utama yang mempengaruhi belajar akademis. Suasana ruangan menunjukkan arena belajar yang dipengaruhi emosi. Penelitian menunjukkan bahwa para siswa menyebut kualitas hubungan mereka dengan guru sebagai faktor paling utama dalam kaitannya dengan kenyamanan dalam belajar. 
Lingkungan yang banyak memberikan tekanan mental dan stress akan menghambat kinerja otak, sehingga siswa akan kesulitan untuk menyerap informasi yang disampaikan oleh guru selama proses belajar mengajar. Goleman berpendapat, "Seseorang dapat berkonsentrasi paling baik saat mereka sedikit dituntut dari biasanya, dan mereka memberikan lebih dari biasanya. Jika tuntutan terlalu sedikit, orang akan menjadi bosan, jika tuntutan terlalu besar untuk di atasi, mereka akan menjadi cemas" (DePorter, 2004:23). Oleh karena itu, menjadi sangat penting bagi seorang guru untuk dapat menciptakan kondisi fisik maupun mental yang nyaman dan mendukung untuk melakukan aktivitas belajar bagi siswa.

Salah satu cara yang dapat dilakukan oleh guru antara lain, melakukan senam otak. Senam otak adalah serangkaian gerakan tubuh yang sederhana digunakan untuk semua bagian otak guna meningkatkan kemampuan belajar. Senam otak sangat baikm dilakukan pada awal proses pembelajaran (Gunawan, 2006:270). Gerakan-gerakan sederhana latihan senam otak dapat menyeimbangkan kembali fungsi-fungsi otak (Frashing, 2007:179)

Gerakan senam otak yang sederhana antara lain : (1) gerakan silang, yaitu menggerakan tangan kanan bersamaan dengan kaki kiri dan tangan kiri bersamaan dengan kaki kanan, bergerak ke depan, ke samping, ke belakang atau jalan ditempat, tangan menyentuh lutut yang berlawanan; (2) 8 tidur, yaitu membuat angka 8 tidur tiga kali tiap tangan, kemudian tiga kali dengan kedua tangan atau juga dapat dilakukan dengan menggunakan siku; (3) coretan ganda, yaitu menggambar dengan kedua tangan pada saat yang sama, ke dalam, ke luar, ke atas, ke bawah; (4) putaran leher, yaitu tundukan kepala ke depan dan pelan-pelan memutar leher dari satu sisi ke sisi lainnya lalu ulangi dengan bahu diturunkan; serta (5) mengisi energi, yaitu duduk di kursi dengan santai dan meletakkan dahi diantara kedua tangan di atas meja, tarik nafas sambil menegakkan kepala, tengkuk dan punggung bagian atas (Dennison, 2002).

Kedua, tahap penyampaian (presentation). Tahap penyampaian dalam siklus pembelajaran dimaksudkan untuk mempertemukan siswa dengan materi belajar yang mengawali proses belajar secara positif dan menarik. Pembelajaran berasal dari keterlibatan aktif dan penuh seseorang siswa dengan pelajaran dan bukan dari mendengarkan presentasi yang tidak habis-habisnya mengenai hal tertentu. Belajar adalah menciptakan pengetahuan, bukan menelan informasi. Tujuan tahap penyampaian adalah membantu siswa menemukan materi belajar yang baru dengan cara yang menarik, menyenangkan, relevan, melibatkan panca indera, dan cocok untuk semua gaya belajar. Otak perlu dihubungkan dengan apa yang diajarkan danapa yang telah diketahui (Silberman, 2000:4). Ketika menerima informasi baru maka otak memutuskan apakah informasi baru tersebut perlu atau tidak untuk dipelajari, otak akan lebih mudah untuk memproses informasi apabila informasi tersebut ada hubungannya dengan informasi yang telah diketahui sebelumnya. Hal ini diperlukan agar proses pemasukan informasi menjadi efektif. Cara yang paling mudah yang dapat dilakukan lah dengan mengajukan pertanyaan yang memancing siswa untuk berpikir dan menghubungkan antara apa yang telah diketahuinya dengan apa yang akan dipelajarinya. Cara lainnya adalah dengan menggunakan poster sebagai pemicu dan melakukan curah gagasan.

Tahap pelatihan merupakan intisari dari berbasis Accelarated Learning, tanpa tahap penting ini tidak ada pembelajaran. Tahap ini dalam siklus pembelajaran berpengaruh terhadap $70 \%$ atau lebih pengalaman belajar secara keseluruhan (Meier, Deve, 2003:145). Pembelajaran akan terganggu jika orang tidak diberi cukup waktu untuk menyerap pengetahuan dan keterampilan baru ke dalam struktur diri mereka saat itu. Bagaimanapun apa yng dipikirkan dan dikatakan serta dilakukan, siswa lah yang menciptakan pembelajaran. Peranan guru hanyalah memprakarsai proses belajar kemudian menyingkir. Tujuan tahap pelatihan adalah membantu siswa mengintegrasikan dan menyerap pengetahuan dan keterampilan baru dengan berbagai cara. Tahap ini dilakukan dengan (1) aktivitas memproses siswa; (2) simulasi dunia nyata; (3) permainan dalam belajar; (4) pelatihan aksi pembelajaran; (5) aktivitas pemecahan masalah; (6) refleksi dan artikulasi individu; (7) dialog berpasangan atau kelompok; (8) pengajaran dan tinjauan kolaboratif; (9) aktivitas praktis membangun keterampilan; (10) mengajar kembali. 


\section{Strategi Direct Intructional}

Direct Intructional adalah strategi pembelajaran yang merupakan bagian dari strategi pembelajaran Ekspositori. Strategi ini menekankan pada penguasaan konsep dan perubahan perilaku dengan mengutamakan pendekatan deduktif, dengan ciri-ciri sebagai berikut: (1) transformasi dan keterampilan secara langsung; (2) pembelajaran berorientasi pada tujuan tertentu; (3) materi pembelajaran yang telah terstuktur; (4) lingkungan belajar yang telah terstruktur; dan (5) distruktur oleh guru. Guru berperan sebagai penyampai informasi, dan dalam hal ini guru seyogyanya menggunakan berbagai media yang sesuai, misalnya film, tape recorder, gambar, peragaan, dan sebaganya. Informasi yang disampaikan dapat berupa pengetahuan prosedural (yaitu pengetahuan tentang bagaimana melaksanakan sesuatu) atau pengetahuan deklaratif, (yaitu pengetahuan tentang sesuatu dapat berupa fakta, konsep, prinsip, atau generalisasi).

Teori pendukung Direct Intructional adalah teori behaviorisme dan teori belajar sosial. Berdasarkan kedua teori tersebut, Direct Intructional menekankan belajar sebagai perubahan perilaku. Jika behaviorisme menekankan belajar sebagai proses stimulusrespons bersifat mekanis, maka teori belajar sosial beraksentuasi pada perubahan perilaku bersifat organis melalui peniruan.

Strategi Direct Intructional (Kardi dan Nur, 2000:2) merupakan suatu pendekatan mengajar yang dapat membantu siswa dalam mempelajari keterampilan dasar dan memperoleh informasi yang dapat diajarkan selangkah demi selangkah. Arends (2001:264) juga mengatakan hal yang sama yaitu: " $A$ teaching strategi that is aimed at helping student learn basic skills and knowledge that can be taught in a step-by-step fashion. For our purposes here, the strategi is labeled the Direct instructionalstrategi".

Menurut Daniel dan David (2008), kelima fase pembelajaran dapat dikembangakan sebagai berikut: (1) Directing. Guru menjelaskan tujuan pembelajaran kepada seluruh kelas dan memastikan bahwa semua peserta didik mengetahui apa yang harus dikerjakan dan menarik perhatian peserta didik pada poin-poin yang membutuhkan perhatian khusus; (2) Instructing. Guru memberikan informasi dan menstrukturisasikannya dengan baik; (3) Demonstrating. Guru menunjukkan, mendeskripsikan, dan membuat strategi dengan menggunakan sumber seperti display visual yang tepat; (4) Explaining and ilustrating. Guru memberikan penjelasan-penjelasan akurat dengan tingkat kecepatan yang pas dan merujuk pada metode sebelumnya; (5) Questioning and discussing. Guru bertanya dan memastikan seluruh perserta didik ikut ambil bagian. Guru mendengarkan dengan saksama jawaban peserta didik dan merespons secara konstruktif untuk mengembangkan belajar peserta didik. Guru menggunakan pertanyaan-pertanyaan terbuka dan tertutup. Guru memastikan bahwa peserta didik dengan semua kemampuan yang dimilikinya terlibat dan memberikan kontribusi di dalam diskusi. Guru memberikan waktu kepada peserta didik untuk memikirkan jawabannya sebelum peserta didik menjawab; (6) Consolidatang. Guru memaksimalkan kesempatan menguatkan dan mengembangkan apa yang perlu diajarkan melalui berbagai macam kegiatan di kelas. Guru dapat pula memberikakan tugas-tugas yang difokuskan dengan baik untuk dikerjakan di rumah; (7) Evaluating pupil's responses. Guru mengevaluasi presentasi hasil kerja peserta didik; (8) Summarizing. Guru merangkum apa yang telah diajarkan dan apa yang sudah dipelajari peserta didik selama dan menjelang akhir pelajaran. Guru mengidentifikasi dan mengoreksi kesalahpahaman. Guru mengundang peserta didik mempresentasikan hasil pekerjaan mereka dan menarik poin-poin serta ide-ide kunci.

\section{Hakikat Motivasi Berprestasi}

Uno (2008) menyatakan"motif adalah sebagai kekuatan yang terdapat dalam diri individu, yang menyebabkan individu tersebut bertindak atau berbuat". Selanjutnya Winkel yang dikutip Uno (2008) menyatakan "motif adalah daya penggerak dalam diri seseorang untuk melakukan aktivitas tertentu, demi mencapai tujuan tertentu".

Jadi apabila ditinjau dari asal katanya yaitu motif maka motivasi berarti segala sesuatu yang mendorong seseorang untuk melakukan aktivitas tertentu demi mencapai tujuan tertentu. Jadi ditinjau dari sektor pendidikan anak, motivasi itu merupakan faktor pendorong dalam belajar. Dimyati dan Mudjiono (2006) menyatakan bahwa "motivasi dipandang sebagai dorongan mental yang menggerakkan dan mengarahkan perilaku manusia termasuk perilaku belajar". 
Dimyati dan Mudjiono (2006) menyatakan ada tiga komponen utama yang mendorong motivasi dalam diri individu, yaitu (a) kebutuhan yang merupakan kebutuhan fisiologi, kebutuhan perasaan aman, kebutuhan sosial, kebutuhan akan pernghargaan diri dan kebutuhan untuk aktualisasi diri; (b) dorongan yang merupakan kekuatan mental yang berorientasi kepada pemenuhan harapan atau pencapaian tujuan; (c) tujuan, yaitu hal yang ingin dicapai individu tersebut.

Dalam kegiatan belajar, motivasi adalah keseluruhan daya penggerak dari dalam diri siswa yang menimbulkan kegiatan belajar, yang menjamin kelangsungan dari kegiatan belajar dan yang memberikan arah pada kegiatan belajar, sehingga tujuan dapat dicapai (Sardiman, 2007). Ciri-ciri adanya motivasi pada seorang siswa dapat diketahui dari pengamatan terhadap perilakunya dalam kegiatan belajar. Ratuman (2002) menyatakan ciri-ciri siswa yang mempunyai motivasi dalam kegiatan belajar antara lain : (1) memperlihatkan motivasi dan perhatian yang serius terhadap apa yang dipelajari; (2) memilki orientasi masa depan; (3) cenderung mengerjakan tugas-tugas belajar yang menantang; (4) memiliki keinginan yang kuat untuk terus berkembang; (5) selalu meyediakan waktu untuk belajar; (6) tekun belajar dan cenderung berupaya menyelesaikan tugas yang diberikan kepadanya.

Motivasi yang banyak mendapat perhatian beberapa ahli psikologi adalah apa yang disebut motivasi berprestasi (achievement motivation). Meclelland dan Atkinson (1948) yang dikutip oleh Nur (2008) menyatakan "motivasi berprestasi atau achievement motivation adalah kecenderungan berupaya sampai berhasil dan memilih kegiatan yang mengarah pada tujuan dan mengarah pada keberhasilan". Selanjutnya Meclelland yang dikutip oleh Ratuman (2002) menyatakan bahwa seseorang mempunyai sisi motivasi untuk bekerja karena adanya kebutuhan untuk berprestasi. Motivasi disini merupakan fungsi dari tiga variabel, yaitu harapan untuk melakukan tugas dengan berhasil, persepsi tentang nilai tugas, dan kebutuhan untuk keberhasilan atau sukses.

Nur (2008) menyatakan bahwa "motivasi berprestasi adalah keinginan untuk mengalami keberhasilan dan berperan serta dalam kegiatan dimana keberhasilan tergantung pada upaya dan kemampuan seseorang“.
Sejalan dengan pendapat Weiner (1992) yang dikutip oleh Nur (2008) "siswa yang memiliki motivasi berprestasi ingin mengharapkan berhasil, apabila ia gagal, mereka akan melipatgandakan upaya mereka sampai mereka benar-benar berhasil". Tidak heran jika siswa yang memiliki motivasi berprestasi cenderung berhasil dalam menyelesaikan tugas-tugas di sekolah. Menurut Sardiman (2007) ciri-ciri orang yang memiliki motivasi berprestasi adalah (a) tekun menghadapi tugas, b) ulet menghadapi kesulitan (tidak mudah putus asa). Tidak memerlukan dorongan dari luar untuk berprestasi sebaik mungkin (tidak cepat puas dengan prestasi yang telah dicapainya), c) lebih senang bekerja mandiri, d) menunjukkan motivasi bermacam-macam masalah, e) cepat bosan pada pekerjaan yang rutin, f) dapat mempertahankan pendapatnya, g) tidak mudah melepaskan hal-hal yang diyakini, h) senang mencari dan memecahkan masalah soal-soal.

Rumusan masalahnya sebagai berikut: (1) Apakah hasil belajar Bahasa Indonesia siswa yang diajarkan dengan strategi pembelajaran berbasis berbasis Accelerated Learning lebih tinggi dibandingkan dengan hasil belajar bahasa Indonesia yang diajarkan dengan strategi pembelajaran Direct Intructional ?; (2) Apakah hasil belajar Bahasa Indonesia yang memiliki motivasi berprestasi tinggi lebih tinggi dibandingkan dengan hasil belajar bahasa Indonesia siswa yang memiliki motivasi rendah ?; dan (3) Apakah terdapat interaksi antara strategi pembelajaran dan motivasi berprestasi terhadap hasil belajar bahasa Indonesia?

\section{METODE}

Penelitian ini akan dilaksanakan di SD Negeri 106162 Medan Estate. Populasi dalam penelitian ini adalah seluruh siswa kelas Va SD Negeri 106162 Medan Estate berjumlah 30 siswa, dan siswa SDIT Al-Hijrah Lau Dendang masing-masing berjumlah $\mathrm{Va}=30$ dan $\mathrm{Vb}=32$ siswa. Sampel merupakan sebagian dari populasi yang dipilih secara representif, artinya karakteristik populasi tercermin dalam sampel yang diambil. Teknik penarikan sampel dalam penelitian ini adalah teknik Cluster Random Sampling. Cluster Random Sampling adalah teknik memilih sebuah sampel dari kelompokkelompok unit yang kecil. Pada tahap pertama, terpilih dua kelas secara random dari tiga kelas V dari SD Negeri 106162 Medan Estate 1(satu) kelas dan dari SDIT Al-Hijrah 1 (satu) kelas 
sebagai kelompok kontrol dan kelompok eksperimen. Kedua kelas memiliki karakteristik relatif sama. Dimana setiap kelas tidak memiliki siswa yang pernah tinggal kelas, umur rata-rata siswa tidak berbeda secara signifikan, menggunakan kurikulum yang sama dan latar pendidikan guru yang sama. Tahap kedua, dari hasil data pengundian dan perundingan masingmasing kelas sebagai tempat pelaksanaan perlakuan dengan penerapan strategi yang berbeda.

Penelitian ini menggunakan metode eksperimen quasi eksperimen (eksperimen semu). Penelitian eksperimen yang menggunakan seluruh subjek dalam kelompok belajar untuk diberikan perlakuan. Penggunaan metode ini terkait dengan subjek penelitian yang tidak dikendalikan secara penuh karena penelitian dilakukan di sekolah dimana berbagai kondisi seperti pembagian kelas, jumlah kelas dan jadwal pembelajaran yang sudah ditentukan sekolah. Akan tetapi seperti strategi pembelajaran berbasis Accelerated Learning dan Direct Intructional dapat di buat dan di atur oleh peneliti.

Rancangan penelitian yang digunakan adalah rancangan faktorial $2 \times 2$. Desain tersebut mampu mengendalikan berbagai faktor yang mempengaruhi validitas internal. Dengan desain ini akan dibandingkan pengaruh strategi pembelajaran berbasis Accelerated Learning dan Direct Instructional terhadap hasil belajar bahasa Indonesia ditinjau dari motivasi berprestasi. Strategi pembelajaran berbasis Accelerated Learning dan Direct Instructional sebagai variabel bebas, motivasi berprestasi tinggi atau rendah sebagai variabel moderator, dan hasil belajar bahasa Indonesia sebagai variabel terikat. Variabel-variabel tersebut dimasukkan ke dalam rancangan penelitian pada tabel 1 di bawah ini.

Tabel 1. Desain Eksperimen Faktorial 2 x 2

\begin{tabular}{|c|c|c|}
\hline Motivasi berprestasi & \multicolumn{2}{|c|}{ Strategi Pembelajaran (A) } \\
\cline { 2 - 3 }$(\mathbf{B})$ & Berbasis Accelerated Learning $\left(\mathrm{A}_{\mathbf{1}}\right)$ & Direct Instructional $\left(\boldsymbol{A}_{2}\right)$ \\
\hline Tinggi $\left(\mathrm{B}_{1}\right)$ & $\mathrm{A}_{1} \mathrm{~B}_{1}$ & $\mathrm{~A}_{2} \mathrm{~B}_{1}$ \\
\hline Rendah $\left(\mathrm{B}_{2}\right)$ & $\mathrm{A}_{1} \mathrm{~B}_{2}$ & $\mathrm{~A}_{2} \mathrm{~B}_{2}$ \\
\hline
\end{tabular}

\section{Keterangan :}

$\mathrm{A}_{1} \quad$ : Strategi pembelajaran berbasis

berbasis Accelerated Learning

$\mathrm{A}_{2} \quad$ : Strategi pembelajaran Direct

Intructional

$\mathrm{B}_{1} \quad$ : Motivasi Berprestasi tinggi

$\mathrm{B}_{2} \quad$ : Motivasi Berprestasi rendah

$A_{1} B_{1}$ : Hasil belajar bahasa Indonesia siswa yang diajar dengan strategi pembelajaran berbasis berbasis Accelerated Learning yang memiliki Motivasi tinggi

$\mathrm{A}_{1} \mathrm{~B}_{2}$ : Hasil belajar bahasa Indonesia siswa yang diajar dengan strategi pembelajaran berbasis berbasis Accelerated Learning yang memiliki Motivasi rendah

$\mathrm{A}_{2} \mathrm{~B}_{1}$ : Hasil belajar bahasa Indonesia siswa yang diajar dengan strategi pembelajaran Direct Intructional yang memiliki Motivasi tinggi

$A_{2} B_{2}$ : Hasil belajar bahasa Indonesia siswa yang diajar dengan strategi pembelajaran Direct Intructional yang memiliki Motivasi rendah

\section{Teknik Analisis Data}

Teknik analisa data pada penelitian ini adalah teknik deskriptif dan inferensial. Teknik deskriptif digunakan untuk mendeskripsikan data hasil penelitian seperti rata-rata hitung, simpangan baku, median, modus, distribusi frekuensi. Sedangkan teknik inferensial yang digunakan menguji hipotesis penelitian adalah teknik analisis varians (ANAVA) dua jalur. Dalam hal ini penggunaan analisis varians, setelah lebih dahulu dilakukan uji persyaratan yaitu uji normalitas dengan menggunakan uji Lilieofors $\left(\mathrm{L}_{\mathrm{o}}<\mathrm{L}_{\mathrm{t}}\right)$ pada taraf signifikan $5 \%$ dengan ketentuan jika ternyata $\mathrm{L}_{\mathrm{o}}<\mathrm{L}_{\mathrm{t}}$ maka data yang diuji berdistribusi secara normal. Selanjutnya untuk uji homogenitas varians dilakukan dengan uji Fisher (F) dan dilanjutkan dengan menggunakan uji Barlett $\chi^{2}{ }_{\mathrm{h}}<\chi^{2}$ t pada taraf signifikan 5\% dengan ketentuan jika ternyata $\chi^{2}{ }_{\mathrm{h}}<\chi^{2}{ }_{\mathrm{t}}$ maka data dinyatakan homogen (Sudjana, 2005).

Hipotesis statistik yang diuji pada penilitian ini meliputi :

1. $\mathrm{H}_{\mathrm{o}}: \mu \mathrm{A}_{1}=\mu \mathrm{A}_{2}$

$\mathrm{H}_{\mathrm{a}}: \mu \mathrm{A}_{1}>\mu \mathrm{A}_{2}$

2. $\mathrm{H}_{\mathrm{o}}: \mu \mathrm{B}_{1}=\mu \mathrm{B}_{2}$

$\mathrm{H}_{\mathrm{a}}: \mu \mathrm{B}_{1}>\mu \mathrm{A}_{2}$ 
3. $\mathrm{H}_{\mathrm{o}}: \mathrm{A}><\mathrm{B}=0$

$\mathrm{H}_{\mathrm{a}}: \mathrm{A}><\mathrm{B} \neq 0$

Keterangan :

$\mu \mathrm{A}_{1} \quad$ : Rerata hasil belajar bahasa Indonesia dari siswa yang memperoleh pembelajaran dengan strategi pembelajaran berbasis Accelerated Learning.

$\mu \mathrm{A}_{2} \quad$ : Rerata hasil belajar bahasa Indonesia dari siswa yang memperoleh pembelajaran dengan strategi pembelajaran Direct Intructional.

$\mu \mathrm{B}_{1} \quad$ : Rerata hasil belajar bahasa Indonesia dari siswa yang memiliki motivasi berprestasi tinggi. $\mu \mathrm{B}_{2} \quad$ : Rerata hasil belajar bahasa Indonesia dari siswa yang memiliki motivasi berprestasi rendah.

Jika hasil analisis varians menunjukkan adanya interaksi (interaction effect) atas variabel bebas dalam hubungannya dengan variabel terikat analisis ditunjukkan dengan analisis varians tahap lanjut untuk anggota kelompok sel yang berbeda dengan uji Scheffe dan uji Tuckey untuk anggota kelompok sel yang sama pada taraf signifikan $5 \%$

\section{HASIL DAN PEMBAHASAN}

Hasil

Data hasil penelitian yang diperlukan untuk melakukan pengujian hipotesis terangkum pada Tabel 2 berikut :

Tabel 2. Data Penelitian

\begin{tabular}{|c|c|c|c|}
\hline $\mathrm{P}_{\text {Motivasi Berprestasi }}^{\text {Strategi Pembelajaran }}$ & $\begin{array}{c}\text { Accelerated } \\
\text { Learning }\end{array}$ & Direct Intructional & Total \\
\hline Tinggi & $\begin{aligned} \mathrm{n} & =16 \\
\sum \mathrm{X} & =516 \\
\sum \mathrm{X}^{2} & =16751,5 \\
\bar{X} & =32,25 \\
\mathrm{Sd} & =2,71 \\
\mathrm{Sd}^{2} & =7,36\end{aligned}$ & $\begin{aligned} \mathrm{n} & =13 \\
\sum \mathrm{X} & =385,5 \\
\sum \mathrm{X}^{2} & =11491,5 \\
\bar{X} & =29,65 \\
\mathrm{Sd} & =2,23 \\
\mathrm{Sd}^{2} & =4,99\end{aligned}$ & $\begin{aligned} \mathrm{n} & =29 \\
\sum \mathrm{X} & =901,5 \\
\sum \mathrm{X}^{2} & =28243 \\
\bar{X} & =61,9 \\
\mathrm{Sd} & =4,94 \\
\mathrm{Sd}^{2} & =12,35\end{aligned}$ \\
\hline Rendah & $\begin{aligned} \mathrm{n} & =14 \\
\sum \mathrm{X} & =327 \\
\sum \mathrm{X}^{2} & =7713,5 \\
\bar{X} & =23,35 \\
\mathrm{Sd} & =2,41 \\
\mathrm{Sd}^{2} & =5,85\end{aligned}$ & $\begin{aligned} \mathrm{n} & =17 \\
\sum \mathrm{X} & =382,5 \\
\sum \mathrm{X}^{2} & =8710,25 \\
\overline{\bar{X}} & =22,5 \\
\mathrm{Sd} & =2,54 \\
\mathrm{Sd}^{2} & =6,50\end{aligned}$ & $\begin{aligned} \mathrm{n} & =31 \\
\sum \mathrm{X} & =709,5 \\
\sum \mathrm{X}^{2} & =16423,75 \\
\bar{X} & =45,85 \\
\mathrm{Sd} & =4,95 \\
\mathrm{Sd}^{2} & =12,35\end{aligned}$ \\
\hline Total & $\begin{aligned} \mathrm{n} & =30 \\
\sum \mathrm{X} & =843 \\
\sum \mathrm{X}^{2} & =24465 \\
\bar{X} & =55,60 \\
\mathrm{Sd} & =5,12 \\
\mathrm{Sd}^{2} & =13,21\end{aligned}$ & $\begin{aligned} \mathrm{n} & =30 \\
\sum \mathrm{X} & =768 \\
\sum \mathrm{X}^{2} & =20201,75 \\
\bar{X} & =51,9 \\
\mathrm{Sd} & =4,77 \\
\mathrm{Sd}^{2} & =11,49\end{aligned}$ & $\begin{aligned} \mathrm{n} & =60 \\
\sum \mathrm{X} & =1611 \\
\sum \mathrm{X}^{2} & =44666,75 \\
\bar{X} & =107,42 \\
\mathrm{Sd} & =10,11 \\
\mathrm{Sd}^{2} & =25,76\end{aligned}$ \\
\hline
\end{tabular}

Berdasarkan data penelitian di atas selanjutnya dilakukan pengujian hipotesis penelitian pertama, kedua dan ketiga dilakukan dengan menggunakan analisis varians faktorial $2 \times 2$. Rangkuman hasil perhitungannya dapat dilihat pada Tabel 3 .

Tabel 3. Rangkuman ANAVA Faktorial $2 \times 2$

\begin{tabular}{|c|r|c|r|r|c|}
\hline Sumber Variasi & \multicolumn{1}{|c|}{ JK } & dk & \multicolumn{1}{c|}{ RJK } & \multicolumn{1}{c|}{$\mathbf{F}_{\text {hitung }}$} & $\mathbf{F}_{\text {tabel }(\boldsymbol{a}=\mathbf{0 , 0 5})}$ \\
\hline A & 93,75 & 1 & 93,75 & 6,56 & 4,02 \\
\hline B & 1007,15 & 1 & 1007,15 & 70,47 & \\
\hline AB & 39,8 & 1 & 39,8 & 4,88 & \\
\hline i (Galat) & 800,3 & 56 & 14,29 & & \\
\hline
\end{tabular}


Berdasarkan hasil di atas maka akan dirinci pengujian hipotesis sebagai berikut :

1. Hipotesis Pertama

Pengujian hipotesis pertama yaitu hasil belajar bahasa Indonesia siswa yang dibelajarkan dengan strategi pembelajaran berbasis Accelerated Learning lebih tinggi daripada hasil belajar bahasa Indonesia siswa yang dibelajarkan dengan strategi pembelajaran Direct Intructional.

Hipotesis statistiknya adalah :

Ho : $\mu \mathrm{SP}_{\mathrm{AL}}=\mu \mathrm{SP}_{\mathrm{DI}}$

$\mathrm{Ha}: \mu \mathrm{SP}_{\mathrm{AL}}>\mu \mathrm{SP}_{\mathrm{DI}}$

Berdasarkan perhitungan ANAVA

faktorial 2 × 2 diperoleh $F_{\text {hitung }}$ sebesar 93,75, sedangakan nilai $F_{\text {tabel }}$ sebesar 4,02 untuk $\operatorname{dk}(1,56)$ dan taraf nyata $\alpha=0,05$. Ternyata $F_{\text {hitung }}=93,75>F_{\text {tabel }}=4,02$. Sehingga pengujian hipotesis menolak $\mathrm{H}_{0}$. Dengan demikian dapat disimpulkan bahwa hasil belajar bahasa Indonesia siswa yang dibelajarkan dengan strategi pembelajaran berbasis Accelerated Learning lebih tinggi dibandingkan dengan strategi pembelajaran Direct Intructional teruji kebenarannya. Hal ini juga terlihat dari rata-rata hasil belajar bahasa Indonesia siswa yang dibelajarkan dengan strategi pembelajaran berbasis Accelerated Learning $(\bar{X}=32,25)$ lebih tinggi dari hasil belajar bahasa Indonesia siswa yang dibelajarkan dengan strategi pembelajaran Direct Intructional $(\bar{X}=29,65)$

Hipotesis Kedua

Pengujian hipotesis kedua yaitu hasil belajar bahasa Indonesia siswa yang dibelajarkan dengan motivasi berprestasi tinggi dan motivasi berprestasi rendah.

Hipotesis statistiknya adalah :

Ho : $\mu \mathrm{MB}_{\text {Tinggi }}=\mu \mathrm{MB}_{\text {Rendah }}$
$\mathrm{Ha}: \mu \mathrm{MB}_{\text {Tinggi }}>\mu \mathrm{MB}_{\text {Rendah }}$

Berdasarkan perhitungan ANAVA faktorial $2 \times 2$ diperoleh $F_{\text {hitung }}$ sebesar 1007,15, sedangakan nilai $F_{\text {tabel }}$ sebesar 4,02 untuk $\operatorname{dk}(1,56)$ dan taraf nyata $\alpha=0,05$. Ternyata $F_{\text {hitung }}=1007,15>F_{\text {tabel }}=4,02$. Sehingga pengujian hipotesis menolak $\mathrm{H}_{0}$. Dengan demikian dapat disimpulkan bahwa hasil belajar bahasa Indonesia siswa yang dibelajarkan dengan motivasi berprestasi tinggi dan motivasi berprestasi rendah teruji kebenarannya. Hal ini juga terlihat dari rata-rata hasil belajar bahasa Indonesia siswa yang dibelajarkan dengan motivasi berprestasi tinggi $(\bar{X}=27,87)$ lebih tinggi dari hasil belajar bahasa Indonesia siswa yang dibelajarkan dengan motivasi berprestasi rendah $(\bar{X}=26,90)$

Hipotesis Ketiga

Pengujian hipotesis ketiga yaitu interaksi strategi pembelajaran dan motivasi berprestasi terhadap hasil belajar bahasa Indonesia.

Hipotesis statistiknya adalah :

Ho : $\mu \mathrm{SP}><\mu \mathrm{MB}=0$

Ha : $\mu \mathrm{SP} \quad<\mu \mathrm{MB} \neq 0$

Berdasarkan perhitungan ANAVA faktorial 2 x 2 diperoleh $F_{\text {hitung }}$ sebesar 39,8, sedangakan nilai $F_{\text {tabel }}$ sebesar 4,02 untuk $\operatorname{dk}(1,56)$ dan taraf nyata $\alpha=0,05$. Ternyata $F_{\text {hitung }}=39,8>F_{\text {tabel }}=4,02$. Sehingga pengujian hipotesis menolak $\mathrm{H}_{0}$. Dengan demikian dapat disimpulkan bahwa terdapat interaksi antara strategi pembelajaran dan motivasi berprestasidalam memberikan pengaruh terhadap hasil belajar bahasa Indonesia teruji kebenarannya.

Selanjutnya dilakukan uji Scheffe. Rangkuman perhitungan uji Scheffe tertera pada Tabel 4.

Tabel 4. Rangkuman Hasil Uji Scheffe

\begin{tabular}{|c|c|c|c|}
\hline \multicolumn{2}{|c|}{ Hipotesis Statisitk } & $\mathbf{F}_{\text {hitung }}$ & $\mathbf{F}_{\text {tabel }(\mathbf{3 , 5 6})(\boldsymbol{\alpha}=\mathbf{0 , 0 5})}$ \\
\hline $\mathrm{H}_{0}: \mu_{11}=\mu_{12}$ & $\mathrm{H}_{\mathrm{a}}: \boldsymbol{\mu}_{11}>\mu_{12}$ & 6,43 & 2,78 \\
\hline $\mathrm{H}_{0}: \mu_{11}=\mu_{21}$ & $\mathrm{H}_{\mathrm{a}}: \mu_{11}>\mu_{21}$ & 1,84 & 2,78 \\
\hline $\mathrm{H}_{0}: \mu_{11}=\mu_{22}$ & $\mathrm{H}_{\mathrm{a}}: \boldsymbol{\mu}_{11}>\mu_{22}$ & 7,41 & 2,78 \\
\hline $\mathrm{H}_{0}: \mu_{12}=\mu_{21}$ & $\mathrm{H}_{\mathrm{a}}: \mu_{12}>\mu_{21}$ & 4,32 & 2,78 \\
\hline $\mathrm{H}_{0}: \mu_{12}=\mu_{22}$ & $\mathrm{H}_{\mathrm{a}}: \mu_{21}>\mu_{22}$ & 5,14 & 2,78 \\
\hline $\mathrm{H}_{0}: \mu_{21}=\mu_{22}$ & $\mathrm{H}_{\mathrm{a}}: \mu_{21}>\mu_{22}$ & 5,13 & 2,78 \\
\hline
\end{tabular}

Keterangan :

$\mu_{11}$ : Rata-rata hasil belajar bahasa Indonesia yang dibelajarkan dengan strategi pembelajaran berbasis Accelerated Learning dan motivasi berprestasi tinggi. $\mu_{12}$ : Rata-rata hasil belajar bahasa Indonesia yang dibelajarkan dengan strategi pembelajaran Direct Intructional dan motivasi berprestasi tinggi. 
$\mu_{21}$ : Rata-rata hasil belajar bahasa Indonesia yang dibelajarkan dengan strategi pembelajaran berbasis Accelerated Learning dan motivasi berprestasi rendah.

$\mu_{22}$ : Rata-rata hasil belajar bahasa Indonesia yang dibelajarkan dengan strategi pembelajaran Direct Intructional dan motivasi berprestasi rendah.

Secara keseluruhan hasil uji Scheffe menunjukkan dari enam kombinasi perbandingan rata-rata hasil belajar bahasa Indonesia, maka berdasarkan Tabel 18 terdapat enam menunjukkan hasil yang signifikan. Hasil yang signifikan tersebut adalah rata-rata hasil belajar bahasa Indonesia antara kelompok siswa yang dibelajarkan dengan strategi pembelajaran berbasis Accelerated Learning dan motivasi berprestasi rendah dengan kelompok siswa yang dibelajarkan dengan strategi pembelajaran berbasis Accelerated Learning dan motivasi berprestasi tinggi.

Namun demikian terdapat interaksi strategi pembelajaran dengan motivasi berprestasi terhadap kematangan sekolah, hal ini terlihat dari strategi pembelajaran berbasis Rata-rata Hasil Belajar
Accelerated Learning memberikan hasil belajar bahasa Indonesia yang lebih tinggi daripada siswa dengan motivasi berprestasi rendah dan strategi pembelajaran Direct Intructional memberikan hasil belajar bahasa Indonesia yang lebih tinggi pada siswa dengan motivasi berprestasi tingggi daripada siswa dengan motivasi beprestasi rendah juga terbukti. Hal ini diketahui dari rata-rata skor hasil belajar bahasa Indonesia siswa yang dibelajarkan dengan strategi pembelajaran berbasis Accelerated Learning pada siswa dengan motivasi berprestasi tinggi. ( $\bar{X}=32,25)$ lebih tinggi dari siswa dengan motivasi berprestasi rendah $(\bar{X}=$ 23,35) dan rata-rata hasil belajar bahasa Indonesia siswa yang dibelajarkan dengan strategi pembelajaran Direct Intructional pada siswa dengan motivasi berprestasi tinggi $\overline{\bar{X}}=$ $29,65)$ lebih tinggi dari siswa dengan motivasi berprestasi rendah $(\bar{X}=22,5)$.

Interaksi strategi pembelajaran dan motivasi berprestasi ditunjukkan pada Gambar 1 berikut :

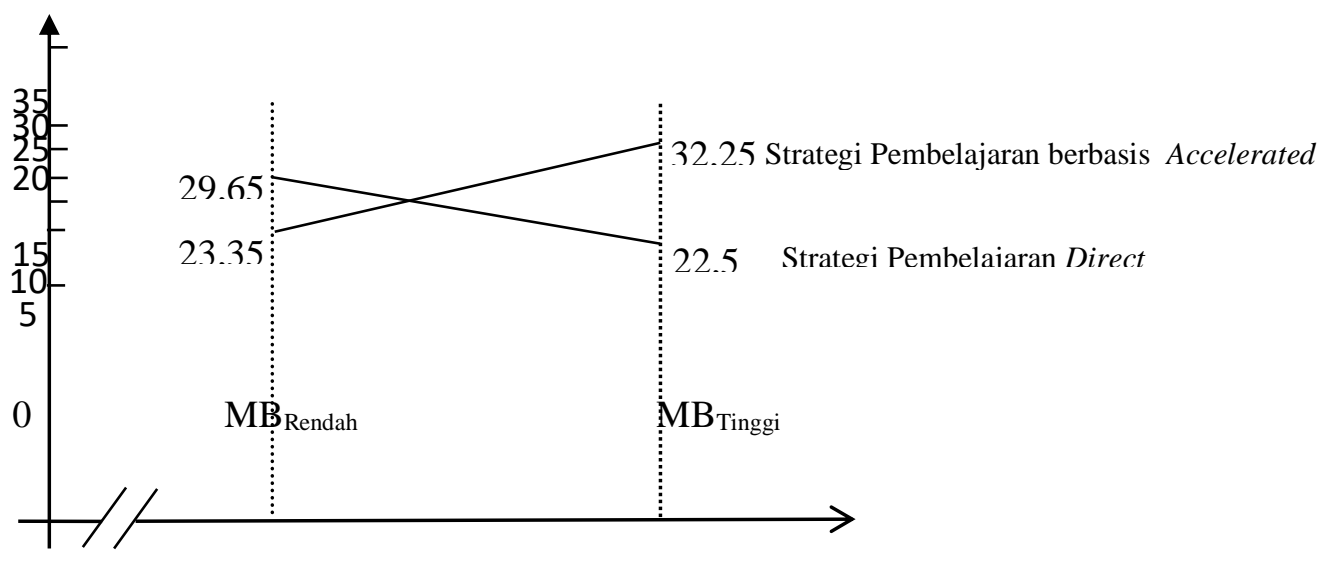

Gambar 1. Interaksi Strategi Pembelajaran dan Motivasi Berprestasi

\section{Pembahasan}

Hipotesis pertama yang menyatakan hasil belajar bahasa Indonesia siswa yang dibelajarkan dengan strategi pembelajaran berbasis Accelerated Learning lebih tinggi dibandingkan dengan siswa yang dibelajarkan dengan strategi pembelajaran Direct Intructional. Hal ini terlihat dari rata-rata hasil belajar bahasa Indonesia siswa yang dibelajarkan dengan strategi pembelajaran Accelerated Learning $(\bar{X}=55,60)$ lebih tinggi daripada rata-rata hasil belajar bahasa Indonesia siswa yang dibelajarkan dengan strategi pembelajaran Direct Intructional $(\bar{X}=51,9)$. Hal ini menunjukkan bahwa strategi pembelajaran Accelerated Learning terbuktif efektif untuk meningkatkan hasil belajar bahasa Indonesia siswa, baik untuk kelompok siswa dengan motivasi berprestasi tinggi maupun siswa dengan motivasi berprestasi rendah. Hasil temuan ini menunjukkan bahwa untuk mengajarkan materi bahasa Indonesia lebih baik menggunakan strategi pembelajaran berbasis Accelerated Learning daripada dengan menggunakan strategi pembelajaran Direct Intructional. 
Melalui perolehan hasil belajar bahasa Indonesia yang dilakukan dalam penelitian ini mendukung ketercapaian tujuan pembelajaran bahasa Indonesia sebagaimana diamanatkan oleh tuntutan kurikulum mata pelajaran bahasa Indonesia adalah : (1) berkomunikasi secara efektif dan efisien sesuai dengan etika yang berlaku, baik secara lisan maupun tulis, (2) menghargai dan menggunakan bahasa Indonesia dengan baik dan benar, (3) memiliki kesadaran tentang hakikat dan pentingnya bahasa Indonesia, (4) menggunakan bahasa Indonesia untuk meningkatkan kemampuan intelektual, serta kematangan emosional dan sosial, (5) menikmati dan memanfaatkan karya sastra untuk memperluas wawasan serta meningkatkan pengetahuan dan kemampuan berbahasa, dan (6) mengembangkan pemahaman tentang keterkaitan antara bahasa dengan budaya.

Pengujian hipotesis kedua menunjukkan bahwa siswa yang memiliki motivasi berprestasi tinggi memperoleh hasil belajar bahasa Indonesia lebih tinggi daripada siswa yang memiliki motivasi berprestasi rendah. Hal ini membuktikan bahwa motivasi berprestasi signifikan untuk membedakan hasil belajar bahasa Indonesia. Motivasi berprestasi dalam penelitian ini dikategorikan atas dua kategori yaitu tinggi dan rendah. Dari hasil analisis data secara keseluruhan diperoleh ratarata hasil belajar bahasa Indonesia siswa dengan motivasi berprestasi tinggi, lebih tinggi daripada hasil belajar bahasa Indonesia siswa dengan motivasi berprestasi rendah. Hal ini menunjukkan bahwa siswa yang memiliki motivasi berprestasi tinggi secara rata-rata memiliki hasil belajar bahasa Indonesia lebih tinggi dibandingkan dengan siswa dengan motivasi berprestasi rendah. Dengan demikian siswa dengan motivasi berprestasi tinggi lebih memahami dan menguasai materi ajar atau keterampilan berbahasa yang dibelajarkan dibandingkan siswa yang memiliki motivasi berprestasi rendah.

Pengujian hipotesis ketiga terdapat interaksi antara strategi pembelajaran dan motivasi berprestasi terhadap hasil belajar bahasa Indonesia siswa. Apabila dilihat ratarata hasil belajar bahasa Indonesia pada kelompok siswa dengan motivasi berprestasi tinggi yang dibelajarkan dengan strategi pembelajaran berbasis Accelerated Learning lebih tinggi dibandingkan dengan rata-rata hasil belajar bahasa Indonesia pada kelompok siswa dengan strategi pembelajaran Direct Intructional. Kemudian rata-rata hasil belajar bahasa Indonesia dengan motivasi berprestasi rendah yang dibelajarkan dengan strategi pembelajaran berbasis Accelerated Learning lebih rendah dibandingkan dengan rata-rata hasil belajar bahasa Indonesia dengan motivasi berprestasi rendah yang dibelajarkan dengan strategi pembelajaran Direct Intructional. Hal ini berarti bahwa bagi kelompok siswa dengan motivasi berprestasi rendah lebih baik menggunakan strategi pembelajaran Direct Intructional dibandingkan dengan menggunakan strategi pembelajaran berbasis Accelerated Learning. Dengan demikian dapat ditarik kesimpulan bahwa strategi pembelajaran dan motivasi berprestasi signifikan mempengaruhi hasil belajar bahasa Indonesia.

\section{PENUTUP}

Simpulan yang dapat diambil dari penelitian ini adalah :

1. Hasil Belajar Bahasa Indonesia Siswa Kelas V SD Negeri 106162 Medan Estate dan SDIT Al-Hijrah 2 Lau Dendang yang diajar dengan strategi pembelajaran berbasis Accelerated Learning lebih tinggi dibandingkan dengan siswa yang diajar dengan menggunakan strategi pembelajaran Direct Intruction.

2. Hasil Belajar Bahasa Indonesia Siswa yang memiliki motivasi berprestasi tinggi memperoleh hasil yang lebih tinggi dari pada siswa yang memiliki motivasi berprestasi rendah.

3. Terdapat interaksi antara strategi pembelajaran dan motivasi berprestasi dalam mempengaruhi hasil belajar bahasa Indonesia. Untuk peserta didik yang memiliki motivasi berprestasi tinggi dalam meningkatkan hasil belajar bahasa Indonesia lebih efektif diajarkan dengan strategi pembelajaran berbasis Accelerated Learning. Sedangkan untuk siswa yang memiliki motivasi berprestasi rendah lebih efektif menggunakan strategi pembelajaran Direct Intruction untuk meningkatkan hasil belajar dibandingkan dengan menggunakan strategi pembelajaran berbasis Accelerated Learning.

\section{DAFTAR PUSTAKA}

Abin, S.M. (2003). Psikologi Pendidikan. Bandung: Rosda Karya Remaja. 
Arends, R.I.. (2001). Exploring Teaching: An Introduction to Education. New. York: Mc Graw-Hill Companies.

Atkinson, R.L., Atkinson, R.C., Hilgard, E.R. (1983). Introduction To Psychology. San Diego : Harcourt Brace Jovanovich, Publishers.

Brown, H.D. (2000). Principles of Language Learning and Teaching. London: Longman.

Chaer, A. (2003). Linguistik Umum. Jakarta: Rineka Cipta.

Dalyono, M. (2009). Psikologi Pendidikan. Jakarta. Rineka Cipta

Daniel W.B., and David J.B. (2008). The Difficulties in Using a Cost Leadership Strategy in Emerging Markets. International Journal of Emerging Market. 3(2), 125-139. Retrieved from Emerald Journals database.

Dennison, Paul E. \& Dennison, Gail E.. (2002). Brain Gym Teacher's Edition Revised. Jakarta: PT. Grasindo.

DePorter, B. dkk. (2005). Quantum Teaching. Bandung: Kaifa.

Depdiknas .(2006). Permendiknas No 22 Tahun 2006 Tentang Standar Isi. Jakarta : Depdiknas.

Dick, W \& Carey. L. (2006). Systematic Design Of Instruction, Sixth Edition. USA:Scott, Foresman and Company.

Dimyati dan Mudjiono. (2006). Belajar dan pembelajaran. Jakarta: PT. Rineka Cipta.

Gagne, R.M \& Driscoll, Marcy. P. (1989). Essentials of Learning for Instruction. New Jersey: Prentice Hall

Gunawan, A.W. (2006). Genius Learning Strategi. Jakarta: PT. pustaka Utama Gramedia

Hamalik. (2009). Proses Belajar Mengajar. Jakarta: Bumi Aksara

Kardi S. Dan Nur, M. (2000). Pengajaran Langsung. Surabaya: Universitas Negeri Surabaya Universiti Press.

Keraf, G. (2004). Komposisi: Sebuah Pengantar Kemahiran Bahasa. Flores: Nusa Indah

Meier, D. (2005). The Accelerated Learning Handbook. Bandung : Kaifa.

Merrill, M.D. (1991). "A Lesson Based On The Component Display Theory" Intruction Theorys In Action. New Jersey : Lawreace

Miarso, Y. (2007). Menyemai Benih Teknologi Pendidikan. Jakarta: Kencana
Miller, J.P and Seller, W. (1985). Curriculum : Perpective and Practice Logman : New York

Nggermanto. (2001). Quantum Quotiont, Kecerdasan Quantum, Cara Cepat Melejitkan IQ,EQ, DAN SQ Secara Harmoni. Bandung: Nuansa.

Nur, E. , Baharudin, H,. Wahyuni. (2008). Teori Belajar dan Pembelajaran. Yogyakarta: Ar-Ruzz Media.

Prashnig, B. (2007). The Power of Learning. Bandung: Mizan Pustaka.

Ratumanan. (2002). Model Pembelajaran Menciptakan Proses Belajar Mengajar yang Kreatif dan Efektif. Jakarta: Bumi Aksara

Reigeluth, C.M. (1983). Instructional Design Theories and Models : An Overview of Their Currect Status. London: lauwrence erlbaums Assosiates

Rose, C. dan Nicholl, M.J. (1997) .Accelerated Learning For the 21 st century.London.

Sardiman. (2007). Interaksi motivasi \& Belajar Mengajar. Jakarta. RajaGrafindo Persada

Silberman, Melvin L. (2007). Active Learning Strategi Pembelajaran Aktif. Yogyakarta: Pustaka Insan Madani.

Sudjana, N. (2009). Penilaian Hasil Belajar Mengajar. Bandung: Remaja Rosdarika.

Sudjana, N. (2002). Metode Statistik. Edisi ke5. Bandung: Tarsito

Sudjana, N \& Suwariyah, W. (1991). ModelModel Mengajar CBSA. Bandung: Sinar Baru Bandung

Sukmadinata.S.N (2008). Landasan Psikologi Proses Pendidikan. Bandung: Remaja Rosdakarya.

Sumantri, S. , Jujun. (2005). Falsafat Ilmu. Jakarta: Pustaka Sinar Harapan

Uno, H. (2009). Model-Model Pembelajaran. Jakarta: Bumi Aksara

Uno, H. (2007). Teori Motivasi dan Pengukurannya. Jakarta : Bumi Aksara

Weiner, D.M. (1992). Divorce busting: A stepbystep approach to making your marriage loving again. New York: A Fireside Book.

Yamin, M. (2011). Paradigma Baru Pembelajaran. Jakarta: Gaung Persada Pers 